\title{
Characterization of Calcium Carbonate Obtained from Oyster and Mussel Shells and Incorporation in Polypropylene
}

\author{
Michele Regina Rosa Hamester, Palova Santos Balzer ${ }^{\mathrm{a}}$, Daniela Becker ${ }^{\mathrm{b} *}$ \\ anstituto Superior Tupy - IST, Rua Albano Schmidt, 3333, CEP 89206-001, Joinville, SC, Brasil \\ ${ }^{\mathrm{b}}$ Departamento de Engenharia de Produção e Sistemas, Universidade Estadual de Santa Catarina - UDESC, \\ Campus Universitário Prof. Avelino Marcante, sn, Bom Retiro, CEP 89223-100, Joinville, SC, Brasil
}

Received: March 25, 2011; Revised: January 24, 2012

\begin{abstract}
There is a high content of calcium carbonate in mussel and oyster shells, which can be used in the formulation of medicine, in construction or as filler in polymer materials. This work has as its main objective to obtain calcium carbonate from mussel and oyster shells and used as filler in polypropylene compared their properties with polypropylene and commercial calcium carbonate composites. The shellfish was milling and heated at $500{ }^{\circ} \mathrm{C}$ for 2 hours. The powder obtained from shellfish were characterized by scanning electron microscopy (SEM), X-ray fluorescence, particle size distribution and abrasiveness and compared with commercial $\mathrm{CaCO}_{3}$ and mixed with polypropylene. The thermal and mechanical properties of polypropylene with $\mathrm{CaCO}_{3}$ obtained from oyster and mussel shells and with commercial $\mathrm{CaCO}_{3}$ were analysed. The results showed that $\mathrm{CaCO}_{3}$ can be obtained from oyster and mussel shell and is technically possible to replace the commercial $\mathrm{CaCO}_{3}$ for that obtained from the shells of shellfish in polypropylene composites.
\end{abstract}

Keywords: oyster shell, mussel shell, calcium carbonate, polymer

\section{Introduction}

Aquaculture is an important source of animal protein for human consumption. In South America, Brazil is second in production of shellfish, following Chile ${ }^{1}$. The state of Santa Catarina is responsible for more than $90 \%$ of Brazilian production of cultivated oysters and mussels. Bivalve shellfish production consists in the cultivation of the Mitilidae family represented by the perna perna mussel and the Ostreidae family, represented by the pacific oyster Crassostrea gigas ${ }^{2}$.

After harvest, the product for the market (the shellfish meat) can go through a beneficiation process to improve its appearance and add value. In these units, the mussels are cooked by steaming or immersion and the shell is removed. Of the entire amount of shellfish produced, 75 to $90 \%$ consists of shells. These shells are composed of $95 \%$ calcium carbonate, and the remainder is organic matter and other compounds ${ }^{3}$. The mussel and oyster shells are discarded into the environment. The improper disposal of solid waste from shellfish cultivation decreases water oxygen and microalgae that are responsible for the nutrition of mussels and oysters, thus hindering the growth of these shellfish ${ }^{4}$.

Concern about the destination of oyster and mussel waste is not only observed in Brazil. In Korea, for example about 300,000 t of oyster shells are generated annually. The Korean government, concerned with public health, financed a project to increase recycling of this waste, because if this waste has been left untreated for a long time, it can

*e-mail: dep2db@joinville.udesc.br be a source of nasty smell as a consequence of the decay of flesh remnants attached to the oyster or the microbial decomposition of salts into gases such as $\mathrm{NH}_{3}, \mathrm{H}_{2} \mathrm{~S}$ and amines $^{5}$. Many studies have investigated the use of oystershell waste as construction materials ${ }^{6-8}$. Another possibility for reuse of these shells is to use them as supplementary feeding ${ }^{9-11}$. Lee and co-workers ${ }^{12}$ demonstrated that crushed oyster shells could be used as an alternative liming material to restore soil chemical and microbial properties in upland soil and to increase crop productivity.

Calcium carbonate is the most widely used filler in terms of the number of applications in polymer. The cheapest grades are low in price and are used primarily to reduce costs. By contrast, the finest grades are an order of magnitude higher in price and are used to modify various properties, both during processing and in the final compounds ${ }^{13}$. Some studies have investigated the use of oyster-shell waste as filler in polymer ${ }^{14-15}$. Chong et al. ${ }^{14}$ prepared mixtures of recycled polyethylene (PE) and oystershell powder, that was coated with ionic surfactant, to test their fire-retardant properties. The mixtures present better mechanical properties and fire-retardant behavior compared with neat recycled PE. Funabashi et al. ${ }^{15}$ evaluated method of biomass carbon ration of polymer filled with calcium carbonate using poly(butylene succinate) (PBS) with oyster shell powder and poly (lactic acid) (PLA) with nobiobased inorganic calcium carbonate. They observed that the estimation method is effective for polymer composites with $\mathrm{CaCO}_{3}$. 
The aim of this work is to obtain calcium carbonate from seafood (mussels and oyster) shells and demonstrate that this material can be reused as filler in polymer, based on thermal, chemical and physical properties of calcium carbonate and mechanical and thermal properties of polypropylene/ calcium carbonate composite.

\section{Materials and Methods}

The polypropylene (PP) and commercial calcium carbonate used in this work were supplied by Braskem and Crenor Carbonatos, respectively, under the tradename PP H604 and Crenor MAX EB respectively. To obtain calcium carbonate, mussel and oyster shells supplied by a restaurant in Joinville, Brazil were used.

The mussel and oyster shells were heated in an oven at $200{ }^{\circ} \mathrm{C}$ for 1 hour to make the shells more brittle and submitted to milling in a high-speed planetary mill with a porcelain jar and alumina balls for 15 minutes with water. The powders are heated again to $500{ }^{\circ} \mathrm{C}$ and maintained for 2 hours and to undo the clusters a new milling was performed without water for 1 minute. The powders were characterized by particle size distribution analyses and chemical composition using a laser diffraction analyzer (CILAS 1064) and X-ray fluorescence (SHIMADZU EDX-700).

Abrasiveness was analyzed using $100 \mathrm{~g}$ of each sample dissolved in distilled water and transferred into the test cup. This cup was conected to a PVC roller which carries 174,000 rounds on the solution in contact with a grille weighed in advance. After the test, the grille was weighed again and the abrasiveness was determined by calculating the mass difference before and after the test, relating to the area subject to abrasion. This technique was performed in an Einlehner AT 1000 device.

Polypropylene composite with commercial $\mathrm{CaCO}_{3}$ and mussel and oyster shells were prepared using a single screw extruder (Ciola B50) set to a length/diameter equal to $25 / 1$, screw rotation rate of $150 \mathrm{rpm}$, with a flat temperature profile along the barrel $\left(180^{\circ} \mathrm{C}\right)$. The composite composition studied was 10 wt. (\%) of $\mathrm{CaCO}_{3}$ and 90 wt. (\%) of neat PP. The composites were injected into a Sandretto Micro 65 injection-molding machine to obtain specimens for tensile and impact tests. The injection molding was carried out with a temperature in the nozzle of $200-225^{\circ} \mathrm{C}$.

The thermal degradation of the calcium carbonate and composites was analyzed in a TA Instruments TG Q200 thermogravimetric analyser in a nitrogen atmosphere. Nonisothermal analysis was performed in a temperature range of 25-800 ${ }^{\circ} \mathrm{C}$, at $10^{\circ} \mathrm{C} / \mathrm{min}$ and nitrogen flow was maintained at $50 \mathrm{~cm}^{3} / \mathrm{min}$.

Charpy impact tests, following ISO 179, were performed on an EMIC Impact tester. Tensile tests, according to ISO 527 standards, were carried out in an EMIC universal testing machine model. Crosshead displacement rate of $10 \mathrm{~mm} / \mathrm{min}$ was used. A longitudinal strain gauge was used to obtain the Young modulus.

The composites were analyzed by differential scanning calorimetry (DSC) to determine the melting temperature, percent of crystallinity and oxidation induction time (OIT). The DSC tests were performed on equipment from TA
Instruments DSC Q20. The OIT analysis was conducting according to ASTM D 3895-98. For determination of melting temperature and percent of crystallinity, the samples were heated at $10{ }^{\circ} \mathrm{C} / \mathrm{min}$ under nitrogen atmosphere. The percent of crystallinity (Xc) was determined from the enthalpy of crystallization of PP, Equation 1, using a value

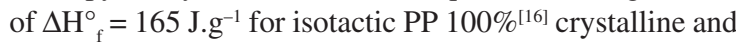
the enthalpy values were corrected for PP weight present in the composite.

$X_{c}=\left(\frac{\Delta H_{\text {amostra }}^{o}}{\Delta H_{f}^{0}}\right) \times 100$

Changes in the morphology in the fracture surface during the impact test of the $\mathrm{PP} / \mathrm{CaCO} 3$ and $\mathrm{CaCO}_{3}$ morphology were observed in scanning electron microscopy (SEM) Zeiss DSM. The samples were first coated with a thin gold layer.

\section{Results and Discussion}

Table 1 presents the chemical composition of commercial $\mathrm{CaCO}_{3}$ and mussel and oyster shells. Mussel and oyster shells present a slightly lower, although not significant, amount of calcium oxide $(\mathrm{CaO})$ than commercial calcium carbonate. There are differences in chemical composition because oysters and mussels are water filterer ${ }^{17}$. Kurunczi and co-workers ${ }^{18}$, for example, detected mercury $(\mathrm{Hg})$ and lead $(\mathrm{Pb})$ in mussel shells, because the water where these mussels grew was contaminated. Chou et al. ${ }^{19}$ also detected $\mathrm{Pb}$ in oyster shells in New Orleans. Mussel shells also present a higher quantity of $\mathrm{Fe}_{2} \mathrm{O}_{3}$ than oyster shells, this oxide can influence polymer oxidation when these shells are used as filler in polymer matrix.

Figure 1 presents commercial $\mathrm{CaCO}_{3}$, mussel and oyster shell particle size distribution. It is possible to observe a larger particle size distribution to oyster and mussel shells (Figure 1a,b respectively) than commercial $\mathrm{CaCO}_{3}$. This behavior can be associated with a higher hardness of the shells, because there is a higher concentration of silica in the shells that increases shell hardness ${ }^{20}$ and the milling conditions used was kept constant. Commercial calcium carbonate grinding consists in several stages with different grinding systems, until it reaches the average particle size most appropriate to use ${ }^{13}$.

The MEV photomicrographs for commercial $\mathrm{CaCO}_{3}$, mussel and oyster shell are shown in Figure 2. It is observed that both the oyster and mussel shells (Figure 2a,b,

Table 1. Chemical composition of shellfish and commercial $\mathrm{CaCO}_{3}$

\begin{tabular}{lccc}
\hline Oxides & Mussel (\%) & Oyster (\%) & $\mathbf{C a C O}_{3}(\%)$ \\
\hline $\mathrm{CaO}$ & 95.7 & 98.2 & 99.1 \\
$\mathrm{~K}_{2} \mathrm{O}$ & 0.5 & - & 0.4 \\
$\mathrm{SiO}_{2}$ & 0.9 & - & - \\
$\mathrm{SrO}$ & 0.4 & - & - \\
$\mathrm{Fe}_{2} \mathrm{O}_{3}$ & 0.7 & - & - \\
$\mathrm{SO}_{3}$ & 0.7 & 0.7 & - \\
$\mathrm{MgO}_{2}$ & 0.6 & - & - \\
$\mathrm{Al}_{2} \mathrm{O}_{3}$ & 0.4 & - & - \\
\hline
\end{tabular}


respectively) contain higher concentration of fine particles and there is also some presence of larger particles which lead to more heterogeneous distribution compared to the commercial $\mathrm{CaCO}_{3}$ (Figure 2c). These results are also being observed in particle size distribution curves of Figure 1. The shape of the oyster and mussel shells particles is more irregular than commercial $\mathrm{CaCO}_{3}$.

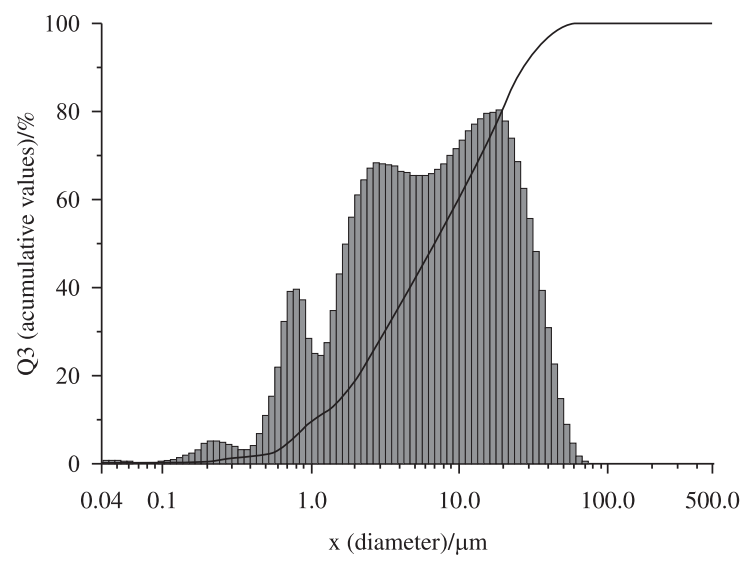

(a)

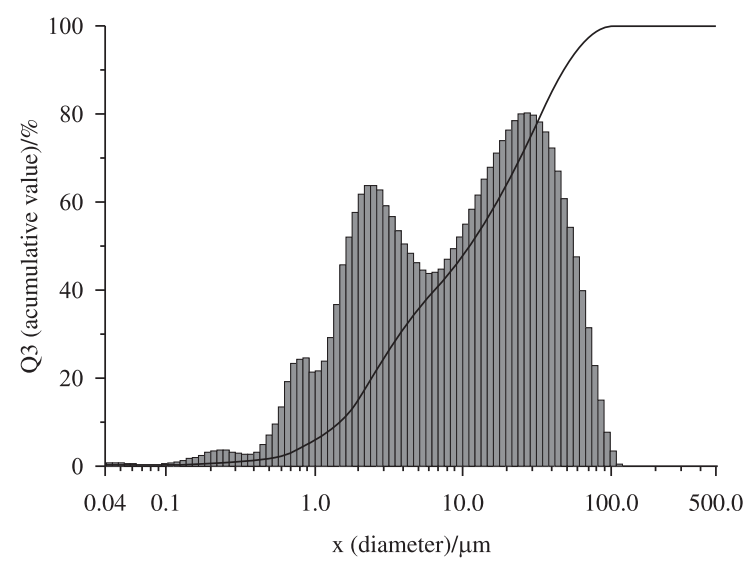

(b)

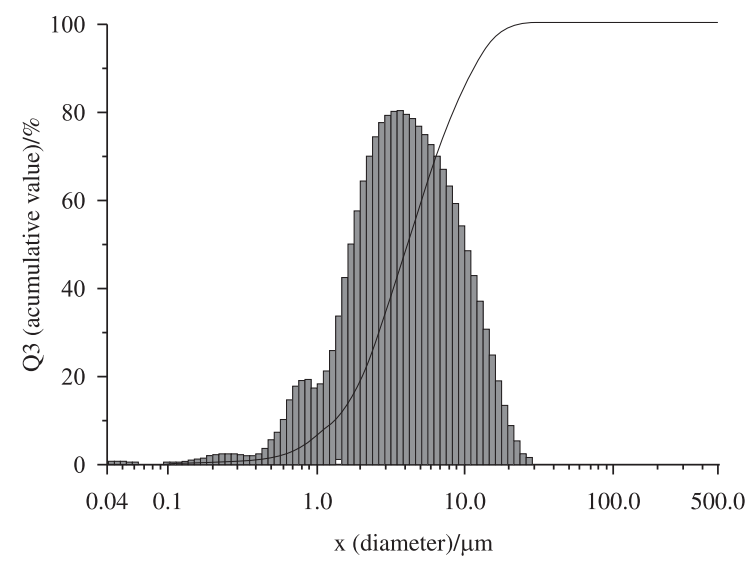

(c)

Figure 1. Particle size distribution of a) oyster and b) mussel shells; c) commercial $\mathrm{CaCO}_{3}$.
The abrasiveness test showed that the commercial $\mathrm{CaCO}_{3}$, mussel and oyster shells were 32, 28, 32 g.cm respectively, showing no significant variation in this property under the conditions tested.

Thermogravimetric analysis (TGA) and first derivative TG curve $\left[(\mathrm{d}(\mathrm{TG}) / \mathrm{dT})\right.$ denoted by DTG] of $\mathrm{PP} / \mathrm{CaCO}_{3}$ composites are shown in Figure $3 \mathrm{a}, \mathrm{b}$ and the data are simplified in Table 2. Although the oyster and mussel shells contain other oxides in chemical composition, these did not influence significantly the behavior of thermal stability compared to the PP with commercial $\mathrm{CaCO}_{3}$. Composites of PP with oyster or mussel presented higher temperature of onset decomposition (dO) and maximum of decomposition (doff).

Melting temperature $(\mathrm{Tm})$, percent of crystallinity $\left(\mathrm{X}_{\mathrm{c}}\right)$ and oxidation induction time (OIT) of $\mathrm{PP} / \mathrm{CaCO}_{3}$ composites are shown in Table 3. It can be noted that $\mathrm{CaCO}_{3}$ obtained from mussel and oyster shells do not show any significant difference in melting temperature and percent of crystallinity compared to the composite with commercial $\mathrm{CaCO}_{3}$.

Oxidation induction time is lower for the composites containing $\mathrm{CaCO}_{3}$ obtained from oyster and mussel shells compared to the composite with commercial $\mathrm{CaCO}_{3}$. This behavior can be explained by differences in chemical composition of the fillers. The mussels showed $0.715 \%$ $\mathrm{Fe}_{2} \mathrm{O}_{3}$, oyster shells less than $0.2 \%$ and in commercial $\mathrm{CaCO}_{3}, \mathrm{Fe}_{2} \mathrm{O}_{3}$ was not detected. According Paoli ${ }^{21}$ transition metal oxide (including iron) can catalyze polyolefin

Table 2. Degradation temperature of PP with oyster shell powder, mussel shell powder and commercial $\mathrm{CaCO}_{3}$ from TG and DTG curves.

\begin{tabular}{lcc}
\hline Composites & dO $\left({ }^{\circ} \mathbf{C}\right)$ & doff $\left({ }^{\circ} \mathbf{C}\right)$ \\
\hline $\mathrm{PP} / \mathrm{CaCO}_{3}$ & 256 & 401 \\
$\mathrm{PP} /$ mussel shell & 306 & 416 \\
PP/oyster shell & 292 & 421 \\
\hline
\end{tabular}

$\mathrm{dO}$ : temperature of onset decomposition. doff: temperature maximum of decomposition.

Table 3. DSC results of PP with oyster shell powder, mussel shell powder and commercial $\mathrm{CaCO}_{3}$.

\begin{tabular}{cccc}
\hline Composites & $\mathbf{T m}\left({ }^{\circ} \mathbf{C}\right)$ & $\mathbf{X}_{\mathbf{c}}(\boldsymbol{\%})$ & OIT $(\mathbf{s})$ \\
\hline $\mathrm{PP} / \mathrm{CaCO}_{3}$ & 159 & 45 & 84 \\
$\mathrm{PP} /$ mussel & 159 & 50 & 14 \\
PP/oyster & 160 & 46 & 45 \\
\hline
\end{tabular}

Table 4. Mechanical properties of PP with oyster shell powder, mussel shell powder and commercial $\mathrm{CaCO}_{3}$.

\begin{tabular}{cccc}
\hline & $\mathbf{P P} \mathrm{CaCO}_{3}$ & $\mathbf{P P} /$ oyster & PP/mussel \\
\hline $\begin{array}{c}\text { Young's Modulus } \\
(\mathrm{MPa})\end{array}$ & $918( \pm 58.1)$ & $904( \pm 40.4)$ & $902( \pm 49.6)$ \\
$\begin{array}{c}\text { Yield strength } \\
(\mathrm{MPa})\end{array}$ & $33( \pm 1.4)$ & $35( \pm 0.6)$ & $33( \pm 1.0)$ \\
$\begin{array}{c}\text { Elongation of break } \\
(\%)\end{array}$ & $61( \pm 21.3)$ & $38( \pm 18.2)$ & $26( \pm 6.5)$ \\
$\begin{array}{c}\text { Impact strenght } \\
\left(\mathrm{kJ} . \mathrm{m}^{-2}\right)\end{array}$ & $3.2( \pm 0.07)$ & $3.4( \pm 0.42)$ & $3.4( \pm 0.42)$ \\
\hline
\end{tabular}


oxidation. Allen et al. ${ }^{22}$ conducted a test on samples of infrared PP containing silica which detected the presence of carbonyl, evidence of oxidation; the authors argue that the carbonyl formation is more associated with the presence of aluminum, titanium and iron than the presence of silica.
Table 4 summarizes the results for mechanical property tests obtained for all samples studied. It is possible to observe that PP composites with commercial $\mathrm{CaCO}_{3}$ and those obtained from shellfish do not show any significant difference on Young's modulus, yield strength and impact

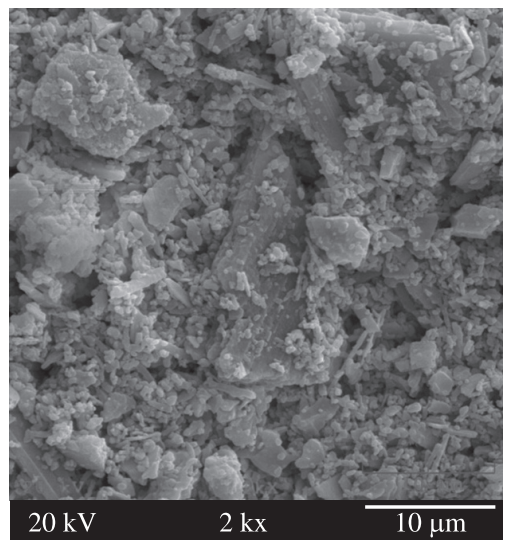

(a)

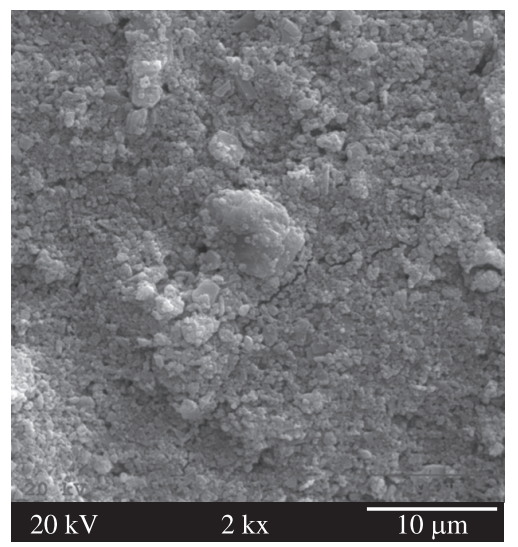

(b)

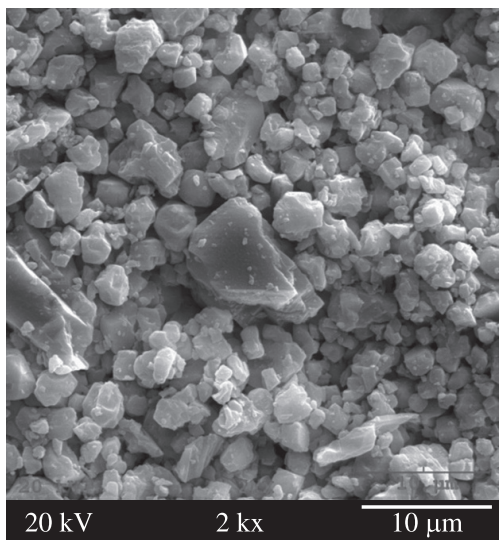

(c)

Figure 2. SEM micrographs of $\mathrm{CaCO}_{3}$ obtained from a) oyster and b) mussel shells; and c) commercial $\mathrm{CaCO}_{3}$.

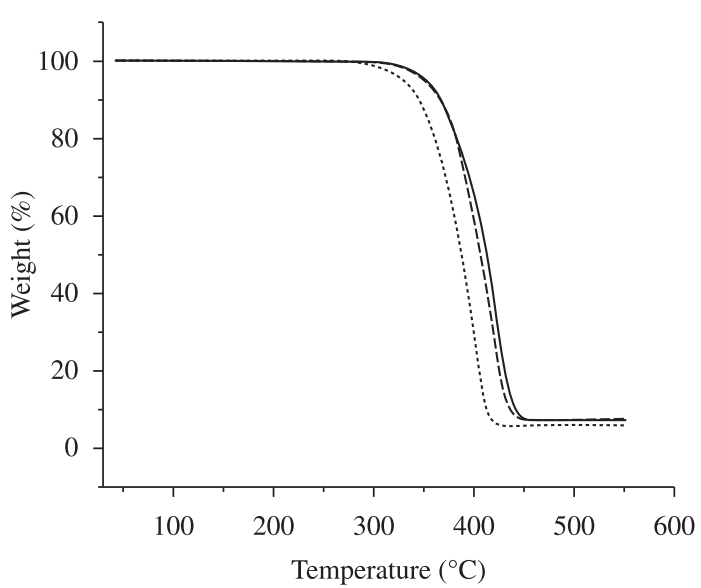

(a)

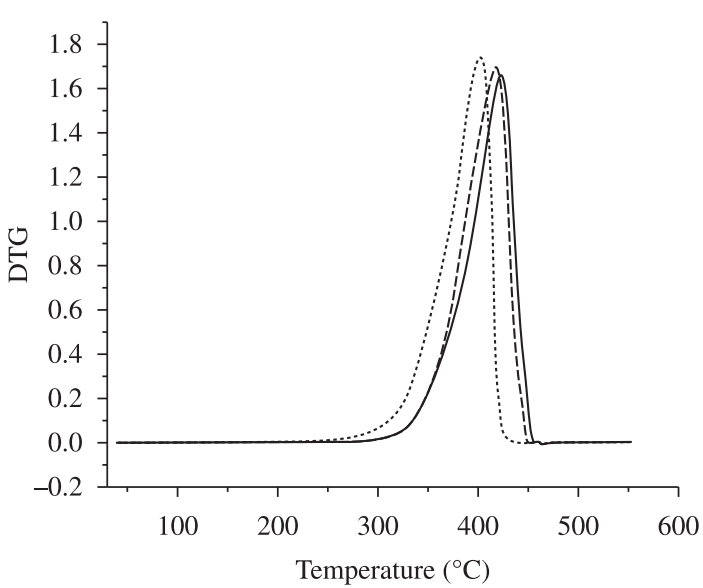

(b)

$$
\text { -..... } \mathrm{PP} / \mathrm{CaCO}_{3} \quad \text {---- } \mathrm{PP} / \text { mussel shell } \quad \text { PP/oyster shell }
$$

Figure 3. a) TG curves and b) DTG curves of PP with oyster shell powder, mussel shell powder and commercial $\mathrm{CaCO}_{3}$.

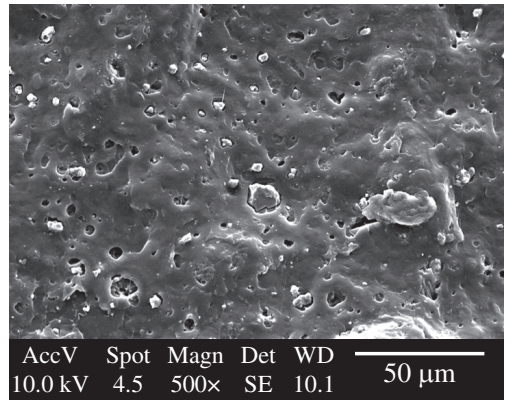

(a)

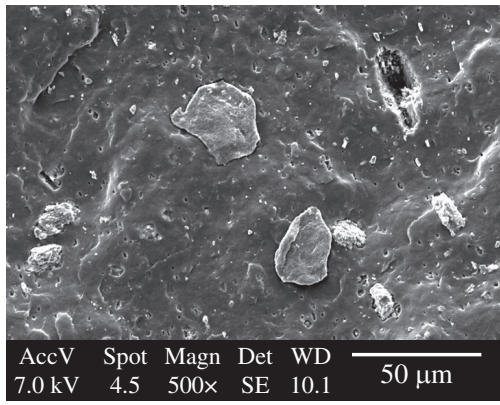

(b)

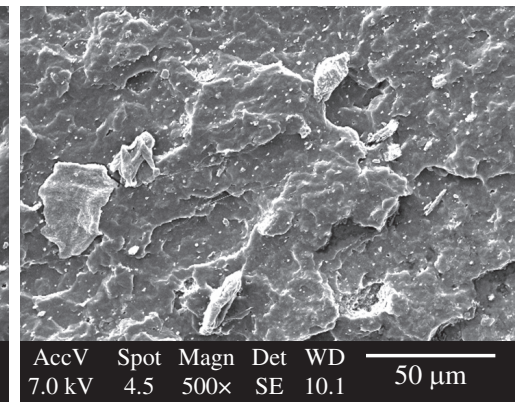

(c)

Figure 4. SEM micrographs of impact test of PP with a) commercial CaCO3; b) mussel shells; and c) oyster shells. 
strength. The composite with commercial $\mathrm{CaCO}_{3}$ showed higher elongation at break than those composites with fillers obtained from shellfish, which can be explained as being due to the particle size distribution.

Sample fractures resulting from impact experiments were analyzed by SEM, as shown in Figure 4. In Figure 4b,c that display the micrographs of the composites with mussel and oyster shells, we can see the large particles and many fine particles of $\mathrm{CaCO}_{3}$ in the PP matrix, while the composite with the commercial carbonate presented particles smaller and more uniform. These differences can justify the smaller deformation at break of PP with shellfish composites. No adhesion between the domains in the matrix can be observed, probably due to the weak interfacial bonding in all composites.

\section{Conclusion}

The results of this study showed that $\mathrm{CaCO}_{3}$ can be obtained from oyster and mussel shells, since both have

\section{References}

1. Souza, RV, Novaes, ALT, Dos Santos, AA, Rupp, GS and Silva, FM. Controle higienico sanitario de moluscos bivalves no litoral de Santa Catarina. Panorama da Aquicultura. 2009; 116:53-59.

2. Silveira FS, Roczanski M, Costa SW, Oliveira Neto FM and Filomeno AN. Desempenho da Pesca e da aqüicultura. In: Centro de Socioeconomia e Planejamento Agrícola - CEPA. Sintese anual da agricultura de Santa Catarina 2006-2007. Joinville: Epagri; 2007.

3. Galtsoff PS. The American Oyster Crassostrea Virginica Gmelin. Fishery Bulletin of the Fish and Wildlife Service. 1964; 64:43-45.

4. Folke C and Kautsky N. The role of ecosystems for a sustainable development of aquaculture. Ambio. 1989; 18:234-243.

5. 5 - Yoon GL, Yoon WY and Chae SK. Shear Strength and compressibility of oyster shell-sand mixtures. Journal Environmetal Earth Sciences. 2010; 60:1701-1709. http:// dx.doi.org/10.1007/s12665-009-0304-1

6. Yoon GL, Kim BT, KIm BO and Han SH. Chemical Mechanical Characteristics of Crushed Oyster-Shell. Waste Management. 2003; 23:825-834. http://dx.doi.org/10.1016/ S0956-053X(02)00159-9

7. Yang E-I, Yi S-T and Leem Y-M. Effect of oyster shell substitute for fine aggregate on concrete characteristics: Part I. Fundamental properties. Cemenet and Concrete Research. 2005; 35:2175-2182. http://dx.doi.org/10.1016/j. cemconres.2005.03.016

8. Yoon H, Park S, Lee K and Park J. Oyster shell as substitute for aggregate in mortar. Waste Management \& Research. 2004; 22:158-170. http://dx.doi. org/10.1177/0734242X04042456

9. Kwon H, Lee C, Jun B, Yun J, Weon S and Koopman B. Recycling waste shell for eutrophication control. Resources, Conservation and Recycling. 2004; 41:75-82. http://dx.doi. org/10.1016/j.resconrec.2003.08.005

10. Faria DE. Sistemas de Alimentação e Suplementação de Farinha de casca de Ostras Sobre o Desempenho e a Qualidade da Casca do Ovo de Poedeiras Comerciais. Revista Brasileira de Zootecnia. 2000; 29:1394-1401. http://dx.doi.org/10.1590/ S1516-35982000000500018

11. Fujita T, Fukase M, Miyamoto H, Matsumoto $\mathrm{T}$ and Ohue $\mathrm{T}$. Increase of bone mineral density by calcium supplement with a similar amount of $\mathrm{CaO}$ to commercial $\mathrm{CaCO}_{3}$. The differences in particles size and distribution of particle size observed are due to the milling conditions used and firing conditions of calcinations that it was kept constant. Analyzing the tensile and impact test results, we can conclude that the composites with commercial $\mathrm{CaCO}_{3}$ and mussel or oyster shells were similar, despite the great difference in particle size and distribution of particle size. For an amount of $10 \%$ load in the PP, there was no significant change in the mechanical properties, which makes this project technically feasible.

\section{Acknowledgements}

The authors want to thank Amanco for the donation of materials and abrasiveness test and Tigre for the particle distribution size analysis.

oyster shell electrolysate. Bone and Mineral. 1990; 11:85-91. http://dx.doi.org/10.1016/0169-6009(90)90017-A

12. Lee CH, Lee D, Ali MA and Kim PJ. Effects of oyster shell on soil chemical and biological properties and cabbage productivity as a liming materials. Waste Management. 2008; 28:27022708. PMid:18294833. http://dx.doi.org/10.1016/j. wasman.2007.12.005

13. Pritchard G. Plastics Additives, An A-Z reference. Springer Verlag; 1998.

14. Chong MH, Byoung CC, Chung YC and Cho BG. Fireretardant plastic material from oyster-shell powder and recycled polyethylene. Journal of Applied Polymer Science. 2006; 99:15831589. http://dx.doi.org/10.1002/app.22484

15. Funabashi M, Ninomiya F, Flores ED and Kunioka M. Biomass carbon ration of polymer composites measured by accelerator mass spectrometry. Journal Polymer Environmetal. 2010; 18:85-93. http://dx.doi.org/10.1007/ s10924-010-0166-3

16. Howe DV. Polypropylene. In: Mark JE. Polymer Data Handbook. Oxford University Press, Inc.; 1999.

17. Levin M. Fish and ShellfishAssociated Disease Outbreaks. Journal of the water pollution control federation. 1978; 50:1377-1381.

18. Kurunczi S, Török S and Chevallier P. A micro-XRF study of the element distribution on the growth front of mussel shell (species of Unio Crassus Retzius). Mikrochimica Acta. 2001; 137:41-48. http://dx.doi.org/10.1007/s006040170026

19. Chou J, Clement G, Bursavich B, Elbers D, Cao B and Zhou W. Rapid detection of toxic metals in non-crushed oyster shells by portable X-ray fluorescence spectrometry. Environmental Pollution. 2010; 158:2230-2234. PMid:20227802. http:// dx.doi.org/10.1016/j.envpol.2010.02.015

20. Rodolfo AJ, Nunes LR and Ormanji W. Tecnologia do PVC. 2th ed. São Paulo: ProEditores; 2006.

21. Paoli MA. Degradação e Estabilização de Polímeros. São Paulo: Artliber; 2009

22. Allen NS, Edge M, Corrales T, Childs A, Liauw CM, Catalina F et al. Ageing and stabilization of filled polymers: an overview. Polymer Degradration and Stability. 1998; 61:183-199. http:// dx.doi.org/10.1016/S0141-3910(97)00114-6 